Revista de Derecho. Vol. 8 (2019), pp. 225-244. ISSN: 1390-440X_eISSN: 1390-7794

Recepción: 30-11-2019. Aceptación: 10-12-2019. Publicación electrónica: 19-12-2019

https://doi.org/10.31207/ih.v8i0.222

\title{
HUMAN RIGHTS, CIVIL SOCIETY, PRIVATE LAW: CORRELATION PROBLEMS
}

DERECHOS HUMANOS, SOCIEDAD CIVIL, DERECHO PRIVADO: PROBLEMAS DE CORRELACIÓN

\author{
Evgen Kharytonov* \\ Olena Kharytonova**
}

\begin{abstract}
The category of "human rights and freedoms", the problems of protection and protection of such rights have repeatedly been the subject of research, but the question of their correlation with concepts such as "civil society", "private law" has not been studied yet. This circumstance determines the expediency of a special study of this issue. Several methodological techniques have been used in the process of exploring issues related to this article. The main ones were civilization and conceptual methods. With the help of the "civilization" method, we explored "law" as a category inseparably related to civilization. The "concept" method helps to consider law in general, and private law as a concept (conceptus from the Latin: thought, representation, concept), that is, as a set of verbal expressions of a social phenomenon denoted by a particular term. In the conclusion, the authors state that there is a conflict in the field of human rights and the conflict of interests of members of civil society, the state resorts to a positive legal regulation of human behavior
\end{abstract}

\footnotetext{
* Doctor of Legal Science. Professor of Civil Law Department and Head of same Department at National University "Odesa Law Academy" (Ukraine). Corresponding Member of National Academy of Law Sciences of Ukraine. Honored Science and Technology Worker of Ukraine. Orcid 0000-0001-5521-0839. zharuton@gmail.com

** Doctor of Legal Science. Professor of Intellectual Property and Corporate Law Department and Head of same Department at National University "Odesa Law Academy" (Ukraine). Corresponding Member of National Academy of Law Sciences of Ukraine. Honored Science and Technology Worker of Ukraine. Orcid 0000-0002-9681-9605. lh2512@gmail.com
} 
(taking into account the national mentality and influencing the formation and transformation of justice in the desired direction). The study reveals that there are no grounds for excessive concern about the "infinity" of human rights. This boundary is usually defined naturally, in the face of the rights and interests of other members of civil society.

Keywords: Civil Law, Concept of Human Rights, European Law, Human Rights, Protection of Human Rights

Resumen: La categoría de "derechos humanos", los problemas de protección y protección de tales derechos han sido objeto de estudio en repetidas ocasiones, pero la cuestión de su correlación con conceptos como "sociedad civil", "derecho privado", no se ha estudiado todavía. Esta circunstancia determina la conveniencia de un estudio especial sobre este tema. Se han utilizado varias técnicas metodológicas en el proceso de exploración de cuestiones relacionadas con este artículo. Los principales fueron la civilización y los métodos conceptuales. Con la ayuda del método civilizatorio, exploramos la "ley" como una categoría relacionada de manera inseparable con la civilización. El método conceptual ayuda a considerar el derecho en general y el derecho privado como un concepto (conceptus del Latín: pensamiento, representación, concepto), es decir, como un conjunto de expresiones verbales de un fenómeno social denotado por un término particular. En conclusión, los autores afirman que existe un conflicto en el campo de los derechos humanos, un conflicto de intereses de los miembros de la sociedad civil, donde el Estado recurre a una regulación legal positiva del comportamiento humano (teniendo en cuenta la mentalidad nacional e influyendo en la formación y transformación de la justicia en la dirección deseada). El estudio revela que no hay motivos para una preocupación excesiva por la "infinidad" de los derechos humanos. Este límite suele definirse naturalmente, frente a los derechos e intereses de otros miembros de la sociedad civil.

Palabras clave: Ley civil, concepto de derechos humanos, derecho europeo, derechos humanos, protección de los derechos humanos

Summary. I. Introduction. II. Methodology. III. Presentation of key research findings. IV. Conclusions. References. 


\section{INTRODUCTION}

The challenges of the $20^{\text {th }}$ Century, the largest of which were the First (Great) and Second World Wars, influenced many traditional values. The Second World War was the impetus for the constitution of "sovereignty of the individual", "the status of the individual." With the adoption of the United Nations Universal Declaration of Human Rights in 1948 and the European Convention for the Protection of Human Rights and Fundamental Freedoms in 1950, there were grounds to call human rights the "fundamental value of the concept of European private law" (cfr. Kharytonov, Kharytonova, Kharytonova, Kolodin \& Tolmachevska, 2019). But if the understanding of the category of "human rights and freedoms", the problems of protection and protection of such rights have repeatedly been the subject of research (Janice, Kay \& Bradley, 1997; Paliyuk, 2003 and 2010; Rabinowitz, 2006; Shevchuk, 2006; Savchin, 2015; Jaskiernia \& Spryszak, 2016), then the question of their correlation with concepts such as "civil society", "private law", etc., has not been studied so far. This circumstance determines the expediency of a special study of this issue.

\section{Methodology}

Several methodological techniques have been used in the process of exploring issues related to this article. The main ones were civilization and conceptual methods. With the help of the "civilization" method, we explored "law" as a category inseparably linked to civilization. From this point of view, the law is an element of socio-political order, as well as an element of social and individual consciousness. In this way, the concept of "right" is understood as a civilizational category that simultaneously acts as an element of socio-political system and an element of social consciousness, is a component of the spiritual world of man and his worldview, and reflects the idea of individuals and society as a whole about justice, good, humanism, etc. This makes it possible to use in the process of research the "concept" method, considering law in general, and private law, in particular, as a concept (conceptus from the Latin: thought, representation, concept), that is, as a set of verbal expressions of a social phenomenon denoted by a particular term. That the definition of a concept is based on an analysis of the concept itself, while the definition of a category is repelled by another category is characteristic. Therefore, the definition of a concept is to convey the meaning of the word to which this 
concept is designated by the elements that the concept forms (Bergel, 2000). This approach is suggested to be taken as the basis for understanding private law, which is the concept of European civilization, with its methodological basis, above all, liberalism. At the same time, the consideration of law as a concept does not deny the legislative content of this concept but eliminates the necessity of obligatory evaluation of it as a system of legal norms that form the field of law, relevant legal institutions, etc.

In this regard, we have the opportunity to move away from a positivist approach based on the recognition of the leading role of "positive" law and to choose the "naturalness of law" as a methodological imperative. The laws of natural law must be embodied in positive law, or in religious precepts, or in the form of customary law. The rule of law should be interpreted as a principle of the rule of law. According to legal naturalism, the primary sources of law are the laws of social nature that are actually existing and in force in the society, which should be opened by people and implemented in the form of positive legislation. Based on legal naturalism, law is a real and socially existing laws in the society, and in particular the laws of natural law, open by humans and embodied by the legislator in the form of positive legislation.

While agreeing with the priority of natural law in the field of human rights protection, we emphasize that this approach is reflected in the modern vision of the essence of law, especially concerning the concepts of "human rights" and "private law" in European civilization (Kharytonov, Kharytonova, Kharytonova, Kolodin \& Tolmachevska, 2019).

\section{Presentation OF KEY RESEARCH FINDINGS}

The expediency of considering matters of private law as a European concept is due to the fact that this category originates and characterizes European civilization, and thus contains axiological guidelines for those who wish to join the European Union.

Considering the fact that European interstate legal systems and the problems of integration with them of the legal system of Ukraine have been the subject of special study (Lutz, 2003), it is inappropriate to dwell on their characteristics. Instead, one should establish the essence of the term "European law", which is used in jurisprudence and as a general concept (that is, as a verbally formed, rational and emotional perception of human rights as part of the world in which this person exists, feeling part of this world) (Anners, 1996; Entin, Naku \& Vodolagin, 2001; Topornin, 
Human rights, civil society, private law: correlation problems

1998) and in respect of particular areas of European legal systems (Tolstopyatenko, 2001; Janice, Kay \& Bradley, 1997).

In doing so, we distinguish between the general concept of "European law", which is an element of European civilization as a whole, and the concept of "European law", in its special meaning, which relates to the regulation of relations arising from the creation and activity of European international organizations. Provided that the former has a common civilizational, "cultural" meaning, we proceed from the fact that it is, by definition, broader than "European law in a special sense", the sphere of which is only the activity and policy of the European Union. The characterization of European Union law as a sui generis phenomenon seems justified (Topornin, 1998), since it is, although closely linked to both international law and the law of different Member States (Tatam, 1998), but constitutes a separate, third system of law which operates alongside with international and domestic law (Muraveiv, 2011).

We support the understanding of European law as a system of legal rules that have arisen in connection with the formation and functioning of the European Communities and the European Union ${ }^{1}$ applied within their jurisdiction on the basis of and in accordance with the founding treaties and the general principles of law (Entin, Naku \& Vodolagin, 2001). At the same time, we consider it worthwhile to pay attention to the final part of the mentioned definition, which refers to the general principles of law, according to which (along with the founding treaties) the rules of European law apply. The Treaty of 1992 provides that

«the Union shall respect the fundamental rights guaranteed by the European Convention for the Protection of Human Rights and Fundamental Freedoms and as they derive from the general constitutional traditions of the Member States as general principles of Community law» (Art. F).

Thus, the general principles of European Union law are based on the priority of the rights of the individual enshrined in the European Convention, which also derives from the constitutional traditions of the European states. The same traditions determine the further development of the national law of the Member States of the European Communities.

The above applies to "European law" and "European Union law" in general, but does not fully take into account the particularities of the "private sphere" of the existence of law. Therefore, there is a need to clarify the nature and characteristics of the concept of "private law", which

\footnotetext{
${ }^{1}$ As a rule, we assume that the terms "European Union law" and "Community law" are interchangeable. Cfr. Kernz, 2002.
} 
can be considered in an objective (as a public phenomenon that determines the legal status of a private person in society) and subjective sense (as a right belonging to an individual).

The central figure of private law (the existence of which is conditioned by the existence of private law) is a private person whose defining characteristics are: (i) is not a person in the state; (ii) is not in the relations of power, neither in subordination to other private persons; and, (iii) is equal and freely, based on the dispositive method of legal regulation, determines for itself the rights and obligations in the relations arising from its initiative (Kharytonov, 2006).

At the level of national legal systems, an individual is (or should be) the main figure of national constitutions and civil law, which is a set of rules and norms concerning the determination of the status and protection of the interests of individuals (private) persons who are not party of the state, which are not found in power or subordination relations, equally and freely establish their rights and responsibilities in the relations arising from their initiative.

In terms of civil law, a human is the main content of the key concept of a "person's status". This makes it desirable to characterize this concept. Therefore, the characterization of this concept is appropriate.

In Latin status means "status" and "state" and denotes (in its original meaning) the position of an individual in society, and the totality of all (or part) of its legal rights and obligations (Bartoshek, 1989). According to this interpretation, the status of a legal entity is usually understood to mean its legal status, which is characterized by the presence of a complex of legal rights and obligations. In doing so, they sometimes equate the notions of "legal status" and "legal state", explaining this to the reason that the category "legal status" covers all types of legal relationships (Halfina, 1974).

However, the equation of these notions is undesirable because it eliminates the differences that exist between the concepts of "the subject of law" and "the subject of legal relations". It is therefore advisable to use different terms to refer to the legal status of the abstract subject and the legal status of a real person, which enters into legal relations.

The notion "status" includes a stable, fundamental in the legal status of the subject, which, together with legal personality, also contains an indication of the existence of a certain range of fundamental rights and duties. Instead, specific rights and duties reflect the specifics of a person's real legal position, which is mainly related to the presence of certain legal facts, not the basis of the subject's general position in that legal system. 
Human rights, civil society, private law: correlation problems

Thus, the legal status of a person can be characterized as a set of fundamental subjective rights and duties, that belong to the subject of the objective law and determine in the most general form of its relationship with the state, based on the provisions of relevant legal rules. It is possible to distinguish the initial legal status of a person in a state established by the Constitution.

Therefore, the legal status is associated with the stable legal position of the subject, and the legal state changes depending on the legal relationship in which it enters.

The characteristic features of the legal status are:

(i) It reflects the state's (society's) determination of the place of the individual in the social communication system. This place is enshrined through the appropriate procedure and in the appropriate legislative form.

(ii) Its content, which has certain stability and changes not because of the will of individuals, but because of the public-legal order as a result of expressing in some way the will of the legislator.

(iii) Elements of legal status: general rights and duties of the subject of the objective law. Its legal responsibility is formulated and exists in the form of legal prescriptions.

(iv) Elements of legal status have the qualities of scale, generality.

They define the boundaries within which a person's legal position, subjective rights, and duties are formed. The presence in the legal status of these attributes allows acting as a legal measure of social freedom (Kuchinskyi, 1978).

The status of a person is not only enshrined in the Constitution but also reflected in the principles of civil law (legislation), by which we understand the fundamental ideas according to which the relations constituting the subject of civil law are regulated. In each of these principles, the vision of the essence of these relations are manifested, certain requirements are put forward for the practical provision of the legal status of an individual.

In this regard, civil law refers to the fundamental ideas according to which the regulation of civil relations is carried out. At the same time, subjective civil rights (including human rights) refer to fundamental ideas that determine the content, limits, and order of exercising such a right.

It may also refer to the "general legal status" and "special legal statuses" of an individual. These concepts are in this case understood as defining a person's position in terms of preference for private or public interest. At the same time, both statuses of the person are stable, they are changed not by the will of the subject, but in public law order. They are the 
totality of the fundamental rights and obligations stipulated by the legal acts in the form of legal abstraction.

It follows that, since acts of legislation can determine both general and special legal statuses, the question arises about the methodological basis for establishing the principles of legislation, which determine the general and special private (civil) status of a person and ensure the differentiation of special statuses.

In our opinion, the primary criterion for the determination should be the consideration of the legal sphere in which the individual resides. After all, the definition of the status of an individual depends on the subject of the relationship in which sphere (private or public) it acts in one way or another. The bases for determining one's status in the aforementioned areas are not and cannot be the same, which is caused by different conceptual approaches to determining one's status in both systems.

As K.F. von Savigny (2011) noted, in public law, the whole (state) is the goal and the individual is subordinate, while in private law, each individual is in itself a goal, and any legal relation to its existence or special position is just a means. In the field of private law, an authorized person defends his or her own interests, the protection is initiated by the subject of interest by filing a civil claim, and thus private rights can be defined as "self-defense of interests". In other areas, the protection of violated interests is initiated by state authorities (Petrazhitskyi, 2000).

In terms of defining the differentiation criteria between private and public legal status of a person, it is important to take into account the provisions of the "willpower theory" of Jellinek, the essence of which is that the right in the subjective sense is understood as a priority of human will, aimed at a particular goods or interest. This priority is recognized and protected by the rule of law. Will is a formal element, and goods (interest) is a material element in subjective law. In turn, individual interests are divided into those that are set primarily for individual purposes (the goals of individuals) and those that are set primarily for social purposes. Recognized mainly for the public interest, the individual interest is the content of public law. Subjective public law (on its material side) is such a right that belongs to an individual based on an individual's status as a member of the state.

Concerning the formal element of rights, the priority of the will, Jellinek distinguishes two types: dürfen (desire, aspiration) and können (opportunity). Dürfen literally translates from the German as «having the desire to do something». Jellinek (2004, p. 376) explains that in this case, «the rule of law recognizes the corresponding actions of the individual as 
Human rights, civil society, private law: correlation problems

permissible, that is, it allows the individual will to exercise his freedom in certain directions». Können means «to be able» and here

«law and order can add to the actions of an individual that something does not belong to an individual by nature (...) namely, to give him or her the right that some of his or her actions will be recognized as legally valid and have legal protection» (Jellinek, 2004, p. 376).

Private subjective law contains both dürfen and können, while public subjective law contains only können. Therefore, in private law, there is always the aspiration (dürfen) and in public law, there is only the possibility (können). Public rights are not based on those allowed, but only on those granted by the authorities. Therefore, they are not part of the natural (regulated by the right of liberty) but are an extension of the rights of natural freedom (Jellinek, 2004).

"Natural" human rights, which are the most important element of its universal status, belong to private law and exist regardless of whether they are recognized as an objective right or not. In other words, they are objective because of their naturalness, inalienability from a person, and can be characterized as being provided by God. Human rights, as a concept of private law, are based on the principles inherent in the branches of the private legal sphere. Such principles include autonomy, voluntariness, legal equality of participants, dispositiveness, coordination, general authorization, legal protection of private interest, etc. (Kolodyi, 1998).

We propose to add to this list the principle of recognition of the crucial importance of humanitarian values, which is a priority for the European mentality. In this approach, human rights are recognized as paramount, while for other types of legal systems, the responsibilities of the individual are the focus. It is only possible to speak of the decisive role of legal obligations concerning the legal system with a public-legal dominant since it is precisely the existence of effective means of public coercion that ensures the fulfillment of obligations by the parties to the legal relationship. Its general principles of European private law are based on the priority of individual rights enshrined in the European Convention. Such traditions define the vector of the development of the national law of the European Union Member States against the background of the growing share of the moral-axiological component of the concept of private law, the unconditional value of which is recognized by human rights and freedoms.

It is worth noting that the concept of private law, as well as the related concepts in the field of human rights, are criticized for "excessive" democracy, the ambiguity of the boundaries of freedoms and human rights in the private sphere, abuse of rights, etc. Liberalism is most criticized 
(Weller, 2007; Pronko, 2014). At times, the expediency of recognizing as a leading criterion the idea of the primacy of human rights in characterizing the tradition of law is called into question, because «from a global perspective, it appears that the only civilization (which is based on the rights of the individual (personality) as the dominant principle) is Western civilization» (Medushevskyi, 2014).

Understanding private law as a concept, which is a set of representations, rules and norms that determine the status of a person (private person) and provide protection of his subjective rights and interests, let us further explore how real it is possible to consider the danger of uncertainty of the boundaries of the rights of the individual criticized by critics of liberalism and individual liberty. In this regard, it should be noted that recognizing a person's right to freely choose a behavior (which does not harm another person) does not in itself pose a threat, since human behavior is moral in nature and moral behavior is one of the most violent sociobiological demarcations (Omelchuk, 2011). However, in cases where there is a conflict in the field of human rights (as well as in the conflict of interests of members of civil society), the state resorts to normative regulation of human behavior. The state takes into account the national mentality and influencing the formation and transformation of consciousness in the desired direction. This approach was reflected, for example, in the conflict decision that emerged when Finland refused to recognize same-sex marriage as legitimate. The European Court of Human Rights explained that while «some countries have expanded the concept of marriage to include a partnership of persons of the same article», European laws granting the right of men and women to free marriage «cannot forcibly extend this concept.» The Grand Chamber of the European Court of Human Rights has found that a State's refusal to recognize same-sex marriage does not violate the European Convention on Human Rights. The Court stated that, although the convention recognizes the possibility of marrying and having a family «as a right of every individual», the document cannot be interpreted as requiring marriage to be transformed into a completely different concept, encompassing same-sex "marriages." The Court also explained that the European Convention on Human Rights «establishes the traditional concept of marriage, which can only exist between a man and a woman.» The applicant cannot claim that such a conclusion does not correspond to «European values that allow same-sex marriages» since there are only 10 in the European Union of these countries and most of the European Union 
Human rights, civil society, private law: correlation problems

members interpret marriage only as a union between a man and a woman (Gennarini, 2014).

In this sense, examples of rigid censorship are also interesting, especially in the field of cinema, where the grounds for restricting the right to marry were determined by considerations for the protection of the human values (Souva, 2008).

Therefore, we can conclude that Western (European) civilization does not abandon traditional "universal" values, although it tries to define their boundary limits. Therefore, concerns about the "boundlessness" of human rights are exaggerated, largely driven by socio-political speculation. This boundary exists and is defined naturally. It is determined by taking into account the rights and interests of other members of civil society. Therefore, let us further consider the relationship between the concepts of "human rights" and "civil society", the emergence of which is associated with the formation of the postulates of humanism and enlightenment (Giro, 2006).

It is worth mentioning here that civil society is sometimes defined by the lens of private law. Thus, Chicherin (1998) believed that civil society is a set of private relations between persons governed by civil or private law. Such an understanding of the essence of civil society, in general, reflects its dominance: the focus on private relations and their regulator.

There is an opinion that civil society (acting as a phenomenon of culture and obeying the common pattern of a culture that defines its structure and development) should reflect its peculiarities. Every civilization, despite the increasing influence of globalization, lives its own life and realizes the cultural potential embedded in it in various spheres, including politics. Each socio-political system corresponds to a specific basic model of civil society, which in each country is manifested in a national-specific form since in the formation of national consciousness, the political culture of the people involved both universalistic and purely national-cultural and historical elements (Trebin, 2013).

In our opinion, in the above position there is a shift of emphasis: the presence of "purely national-cultural and historical elements" does not mean the creation of a "special basic model of civil society". When considering such phenomena, it is necessary to take into account the presence of not only universal and national-special but also separate, "specific". If the universal applies to all socio-political categories, then the individual defines inherent in only certain types of them-one that can be taken as a basis by other systems (serve as "basic" for them) but does not lose its genetic essence. Therefore, it may become "basic" here for borrowing and be accepted by recipients (adapted), but it does not become 
"special basic". Thus, Roman law does not cease to be a "Roman right" because of its reception, and civil society cannot become a "special basic model" in a society where there are no democratic relations, and which does not recognize the existence of private relations.

Therefore, civil society is a phenomenon (force) that exists in a democratic system (the space of democratization). Along with him, there are such forces in the space as the political elite, the economic community (business), the sphere of legislation and the state bureaucracy. The last two components (which are based on general principles of government) constitute the essence of every modern democratic system. All others are certain organizations and groups of people who give the democratic system a specific character. At the same time, when economic and political communities are made up mostly of actors and institutions to gain power or profit, civil society is the sphere of action of ordinary people who unite to express their interests, protect and fulfill everyday needs. Civil society is a collection of independent and constitutionally protected civic organizations, groups and associations voluntarily created by ordinary citizens in various fields (Howard, 2009). It also refers to relations between groups of people, but not all groups, only those based on general liberal principles closely linked to the development of civil society (Howard, 2009) and those which serve as the basis for the concept of private law.

These circumstances make it advisable to consider civil society through the lens of liberalism and the market. From this perspective, civil society is understood as a sphere of social interaction between the economy and the state, consisting primarily of the areas of closest communication (in particular, families), associations (in particular, voluntary), social movements. and various forms of public communication. Modern civil society is created through certain forms of self-constitution and self-mobilization. It is institutionalized and generalized through laws and subjective rights that stabilize social differentiation. Self-creation (independent activity) and institutionalization do not necessarily imply one another, they may exist independently of each other, but in the long run, both of these processes constitute an indispensable condition for the reproduction of civil society (Dzhyn, 2003).

From the point of view of liberalism, the assessment of the meaning of the concept of "human rights" makes it necessary to take into account the peculiarities of the human component of civil society (Zaichuk, Kopilenko \& Onischenko, 2009; Bilenchuk, Gvozdetsky \& Slivka, 1999).

It should be noted that in this case, it is a matter of a new type of person (Bilenchuk, Gvozdetsky \& Slivka, 1999), given that he was formed 
Human rights, civil society, private law: correlation problems

based on the division of labor (thanks to his regulator, the market; cfr. Smith, 2001). Gellner (2004) proposed the category of "modular person", the introduction of which emphasizes that the creation of civil society provides a unique opportunity to achieve individualization and, at the same time, create political associations that balance the state but do not bind their members. The lack of modularity eliminates the possibility of choosing technology based on the principle of efficiency. Instead, every human activity has to be viewed in the light of the many elusive and extremely complex relationships that make it an organic, indivisible cultural entity. But in reality, only the political implications of modularity are relevant. A modular person can enter into effective institutions and associations, which need not be total, ritualized, connected with many connections with other elements of the social whole, entangled in these relationships. It may leave these unions if it does not agree with their policies, and no one accuses it of treason. A market society lives not only in the face of fluctuating prices but also of unions and changing opinions. There is no single price, and there is no single way of dividing people into certain categories: all of this can and must change, and moral standards will not prevent it. Public morality does not come down to a set of rules and regulations; beliefs can change, and this is not considered a sin. The essence of civil society is seen in the formation of effective connections, which, at the same time, are flexible, specialized, instrumental. A significant role here was played by the transition from status relationships to contractual ones: people began to adhere to the contract, even if it did not correlate with the established position in society or belonging to a certain community group. Such a society is still structured, it is not some sluggish, inert mass, on the contrary, its structure is mobile and easily amenable to rational improvement. Consequently, institutions and associations that balance the state but, at the same time, do not bind together at the hands and feet of their members, coexist mainly because of human modularity. The emergence of a modular person made possible the emergence of civil society (Gellner, 2004).

An important clarification should be added to this conclusion: we also take into account that the market determines the emergence of a modular person, and the aggregate of modular individuals forms a civil society. Civil society (as a certain social reflection of the market system) "transcends" the imperatives of the market into formulas of freedom, and formulas of freedom "transcodes" into the social imperatives of democracy. Although a much more rigid determinism prevails in a market society, the fundamental difference of the market is that it allows one to overcome one's personal dependence on the other. Human relations, social 
relations are impersonal. Probably, they can be interpreted as distorted, alienated forms of human being, forms in which things rise above and rule over people, but it cannot be denied that this governance is rationally prudent. At the same time, civil society is not a mere reflection of the market, but rather its "isomorphic reflection". For, as the market is a system of division of labor, so is civil society as a system of distribution (division) of thoughts, ideas and associations; as free-market prices prevailing in the market, so in civil society opinions are expressed freely, public associations that are not subject to the state are formed; as the market lives in the face of changing prices, so in civil society ideas are spontaneously born and die, public opinion changes, people's associations are reformed. And just like in the market, in civil society the decisive lever of reconciling the diversity of supply and demand, pluralism of views and positions, bringing them into system unity (equilibrium), is consent (social contract, consensus) (Pasko \& Pasko, 1999).

Therefore, it seems reasonable to believe that the secret of the phenomenon of civil society is that there is an awareness of market determinants. Since the reflection of market imperatives in civil society is carried out across the spectrum of diverse social groups through the prism of their needs and interests, it becomes impossible for the solidarity of public consciousness and the unanimity of public opinion. Instead, the pluralism of ideas, thoughts and the diversity of political, cultural, professional, and denominational associations that are called upon to identify and form these ideas and thoughts are natural. No longer does the state impose its ideas on society, but on the contrary, civil society expresses its demands to the state. However, such pluralism is not a chaos of ideas. All of these ideas reflect the demands of a market economy in terms of the interests of a particular group. The taboo only imposes on political programs that call for the violent destruction of the social order itself. In such a society, everyone is given the choice within a market paradigm. Thus, civil society becomes an area of spiritual and social freedom. One can talk about the limits of this freedom, but there is no doubt that civil society creates an atmosphere of a subjective sense of freedom in each individual, a sense of choice of thoughts, associations, unions, forms of activity (Pasko \& Pasko, 1999).

Although some researchers believe that the historical process of the twentieth century revealed the inadequacy and danger of the concept of economic liberalism (Afanasyev, 2007), however, the proposal for limited state intervention to alleviate social problems of society does not mean concessions to the ideas of civil society. Thus, defining the essence of civil 
Human rights, civil society, private law: correlation problems

society as a result of the harmony of a diversity of interests and relationships formed between individuals (and associations created by them) existing and operating in a market environment, we can distinguish the features of such a society:

(i) Its emergence as a result of a contract (consensus) between individuals who meet the notion of a "modular person";

(ii) The emergence and existence of it based on liberalism;

(iii) Its existence in the conditions of the developed civilized market;

(iv) The formula of freedom in it is expressed as the social imperatives of democracy;

(v) The basis of relations between people is the activity of a democratic and liberal character;

(vi) It is viewed primarily as a behavioral and institutional phenomenon (unlike "social capital"; Howard, 2009); and,

(vii) The state does not govern civil society, but, after its establishment as a rule of law, is obliged to provide conditions of its functioning and life (Kuznetsova, 2014), since the principle of priority functioning of civil society in relation to state power is becoming more characteristic of the general dynamics of development of modern world civilization (Onishchenko, 2014; Kolodyi, 2014).

However, this concept needs clarification related to the expediency of moving away from a simplified binary vision of elevation: the civil society and the state. Instead, the three-component model in which civil society is separated from both the state and economic structures seems more reasonable, allowing it not only to play an oppositional role under authoritarian regimes but also to revive its critical potential in a liberal democracy. In this case, the rigid "linking" of the concepts of "civil society" and "state" to one another disappears, and thus the opportunity to consider the latter component as a variable that promotes or impedes the development of civil society.

There is no doubt that the possibility of state interaction with civil society is more ensured through public law than through private law. But this is a natural state of affairs since private law and civil society are oneof-a-kind concepts that not only cannot exist without each other, but cannot be sufficiently characterized beyond their interconnectedness, which is related to the homogeneity of the basis of their origin and existence. The need for government intervention in regulating their relations arises because of the divergent interests of people and their groups; civil society-as Hegel noted - resembles a battleground where one private interest is constantly at odds with another. Since civil society cannot cope with these conflicts alone, reconcile disparate interests, it shapes the state 
to achieve this goal by establishing legal relationships and relationships that create governing structures and determine the procedures for their activities and cooperation. Thus, the state power must create optimal conditions for the proper functioning of civil society, protect it, and help to overcome conflict situations. The state that serves civil society is the rule of law (Bilenchuk, Gvozdetsky \& Slivka, 1999) and the basis of their relations is an ideology that can be called "human-centric" (Lotyuk, 2014). In some version, these relations are characterized as follows: «A democratic state power is an effective and active guide to the freedom, physical and spiritual beauty of humans» (Onishchenko, Stoetsk \& Sunyegin, 2014).

This applies not only to the protection of human rights and freedoms but also to the functioning of the market, without which neither civil society nor private law is possible. As Friedrich Hayek emphasized, market society is vainly condemned by anarchy and the non-recognition of a common goal. This is its merit because it makes people free because everyone chooses a goal. When people can live peacefully (without setting imperative goals and subordination), it leads to the creation of a Great Society. Therefore, there is a general problem of choice between the private-legal approach (humanitarian approach) and the public-legal approach (public-regulatory approach) (cfr. Hayek, 1999). The prospect of choice is that replacing the market with a planned economy takes away human freedom. The power that manages all resources controls all aspects of people's lives and activities. There is a single employer, any job, the will of the boss is not discussed. The monarch determines the quantity and quality of what consumers have to buy (Mises, 1999).

Thus, in respect of all these concepts, the state acts as a regulator on demand, and these concepts are guidelines that complement each other in a democratic society, mediating areas: socio-political (civil society), economic (market), legal (private law).

\section{CONCLUSIONS}

Summarizing the results of the study (using civilization and conceptual scientific methods) of the problems of interaction between the categories of "human rights", "private law" and "civil society", we can make the following conclusions.

1. Human rights are the basic value of modern European civilization, which is reflected in the proper definition of the legal status of the person (personality). Legal registration of a set of basic natural human rights is 
Human rights, civil society, private law: correlation problems

usually enshrined in national constitutions, the norms of which in this field are inherently embodying the provisions of natural law at the level of national legislation.

2. In their essence, human rights belong to the private legal sphere. At the same time, the separation of private-law and public-law aspects of human rights has the nature of scientific abstraction, since the issue of the exercise and protection of such rights concerns the sphere of action of both private and public law. This separation is appropriate for scientific analysis, but to find out the real situation of the individual, this approach is not correct, since in practice there is a combination of public-law and private-legal human rights.

3. Public-law remedies are used to protect human rights in the rule of law, as well as in cases of conflicts in the field of human rights, in the event of a conflict of interests of members of civil society, when the state is forced and justified to resort to positive-legal regulation of human behavior, national mentality and influencing the formation and transformation of consciousness in the desired direction.

4. One of the vulnerabilities of the modern concept of private law is the indeterminacy of the boundaries of the rights of the individual, which is often criticized by supporters of "traditional" orthodox values that intimidate the average citizen from the destruction of family values, and the like. In this case, the shortcomings are a continuation of virtues: recognizing a person's right to freely choose behavior that does not harm another person.

5. It should be emphasized that Western (European) civilization does not abandon traditional "universal" values, although it tries (sometimes empirically) to define their boundary boundaries in the event of a conflict with the latter with the rights of the individual.

However, there is a conflict in the field of human rights, as well as the conflict of interests of members of civil society, the state resorts to a positive legal regulation of human behavior, taking into account the national mentality and influencing the formation and transformation of justice in the desired direction. Thus, in our view, there are no grounds for excessive concern about the "infinity" of human rights. This boundary is usually defined naturally, in the face of the rights and interests of other members of civil society. 


\section{REFERENCES}

Afanasyev, V.S. (2007). Adam Smith: The Political Economy of Manufactured Capitalism. Moscow: Eksmo.

Anners, E. (1996). History of European law. Moscow: Science.

Bartoshek, M. (1989). Roman law: (Concepts, terms, definitions). Moscow: Legal lit.

Bergel, J.-L. (2000). General theory of law. Moscow: Nota Bene.

Bilenchuk, P.D., Gvozdetsky, V.D. \& Slivka, S.S. (1999). Philosophy of Law. Kyiv: Attica.

Chicherin, B.N. (1998). The philosophy of law. Saint Petersburg: Science.

Dzhyn, L. K. (2003). Andrew Arato. Civil society and political theory. Moscow: All World Publishing House.

Entin, L.M., Naku, A.A. \& Vodolagin, S.V. (2001). European law. Moscow: NormaInfra.

Gellner, E. (2004). Conditions of freedom. Civil society and its historical rivals. Moscow: Moscow School of Political Studies.

Gennarini, S. (2014). European Court: Gay marriage is not a human right. Retrieved from https://www.lifesitenews.com/news/european-court-gay-marriage-is-nota-human-right (11-XII-2019).

Giro, T. (2006). Political science. Kharkov: Publishing house of the Humanitarian Center.

Halfina, R.O. (1974). General doctrine of legal relationship. Moscow: Legal. lit.

Hayek, F.A. von. (1999). Cognition, competition and freedom. Saint Petersburg: DirectMedia.

Howard, M.M. (2009). The weakness of civil society in post-communist Europe. Moscow: Aspect-Press.

Janice, M., Kay, R., \& Bradley, E. (1997). European Human Rights Law: Sources and Practices. Kyiv: ArtEC.

Jaskiernia, J., \& Spryszak, K. (Eds). (2016). European Human Rights System. Universal inspiration - cultural conditions - implementation barriers. Torun: Adam Marszałek.

Jellinek, G. (2004). General Doctrine of the State. Santi Petersburg.: Publishing House "Legal Center Press".

Kernz, B. (2002). Introduction to European Union law. Kyiv: Knowledge.

Kharytonov, E., Kharytonova, O., Kharytonova, T., Kolodin, D. \& Tolmachevska, Y. (2019). Human rights as the basic value of the concept of private law in modern Europe. Amazonia Investiga, 8(20), 477-485.

Kharytonov, E.O. (2006). Introduction to the Civil Law of Ukraine. Kyiv: Istina. 
Human rights, civil society, private law: correlation problems

Kolodyi, A. (1998). Principles of Law of Ukraine. Kyiv: Jurinkom Inter.

Kolodyi, A. (2014). Civil society: signs, structural elements, relations with the state. Law of Ukraine, 4, 9-12.

Kuchinskyi, V.A. (1978). Personality. Liberty. Right. Moscow: Legal. lit.

Kuznetsova, N. (2014). Civil society, the state, private law: problems of correlation and interaction. Law of Ukraine, 4, 63-70.

Lotyuk, O.S. (2014). The question of the relationship between civil society and the state. Journal of the Kiev University of Law, 11(2), 13-18.

Lutz, A.V. (2003). European interstate legal systems and problems of integration with them of the legal system of Ukraine (theoretical aspects). Kyiv: Institute of State and Law. V.M. Koretsky NAS of Ukraine.

Medushevskyi, A.N. (2014). Is Russian legal tradition a pillar or an obstacle? Report and discussion. Moscow: The Liberal Mission Foundation.

Mises, L. von. (1999). The individual, the market and the rule of law. Saint Petersburg: Pnevma.

Muraveiv, V.I. (2011). European Union law. Kyiv: Jurinkom Inter.

Omelchuk, O.M. (2011). Human behavior: a philosophical and legal dimension. Khmelnitsky: Khmelnitsky University of Management and Law.

Onishchenko, N. (2014). On the question of finding a balance in the relationship between civil society and the state: theoretical and methodological aspects. Law of Ukraine, 4, 55-62

Onishchenko, N.M., Stoetsky, S.V. \& Sunyegin, S.O. (2014). To the question of the responsibility of the state to civil society. Journal of the Kiev University of Law, 2, 9-13.

Paliyuk, V.P. (2003). Peculiarities of the application by the courts of Ukraine of the Convention for the Protection of Human Rights and Fundamental Freedoms. Mikolaev: Atoll.

Paliyuk, V.P. (2010). Article 10 of the Convention for the Protection of Human Rights and Fundamental Freedoms: Ukrainian law and the judiciary. Mykolaiv: Ilion LLC.

Pasko, I.T., \& Pasko, E.I. (1999). Civil society and the national idea. (Ukraine against the backdrop of European processes). Donetsk: CSO of NAS of Ukraine, UK Center.

Petrazhitskyi, L.I. (2000). The theory of law and the state in connection with the theory of morality. Saint Petersburg.: Publishing House "Lan".

Pronko, Y. (2014). Primitivism among jurists is something that is difficult to understand and comprehend. Retrieved from http://www.kasparov.ru/material.php?id =542E433E7DF16\&section_id=50A6C962A3D7C (13-XII-2019).

Rabinowitz, P. (Ed). (2006). Human rights: a socio-anthropological dimension: a collective monograph. Proceedings of the Lviv Laboratory for Human Rights 
and a Citizen of the Research Institute of State Construction and Local SelfGovernment of the Academy of Legal Sciences of Ukraine. Lviv: The World.

Savchin, M.V. (2015). Public Governance, Human Rights and Democracy: A Regional Cross-section of European Integration. Uzhgorod: Hoverla Publishing House.

Savigny, F.K. (2011). The system of modern Roman law. Moscow: Statute.

Shevchuk, S. (2006). Judicial protection of human rights: The case-law of the European Court of Human Rights in the context of the Western legal tradition. Kyiv: Abstract.

Smith, A. (2001). Welfare of Nations: Research on the Nature and Causes of Welfare of Nations. Kyiv: Port-Royal.

Souva, Don B. (2008). 125 Prohibited Films: The Censorship History of World Cinema. Ekaterinburg: Ultra-Culture.

Tatam, A. (1998). European Union Law. "Abris".

Tolstopyatenko, G.P. (2001). European Tax Law. Comparative Legal Research. Moscow: Norm.

Topornin, B.N. (1998). European Law. Moscow: Lawperfyer.

Trebin, M. (2013). The Western Model of Civil Society: A Conceptual Approach. Gilea: a scientific bulletin, 75, 253-257.

Weller, M. (2007). Russia and Recipes. Moscow: AST Publishing House.

Zaichuk, O.V., Kopilenko, O.L. \& Onischenko, N.M. (2009). Modern Legal Encyclopedia. Kyiv: Jurinkom Inter. 